\title{
THE CURRENT STATUS OF ETHNO-CONFESSIONAL AND NATIONAL-STATE IDENTITY OF DAGESTANIS
}

\author{
(C) Yusup Dz. Dzhabrailov \\ Daghestan Scientific Centre of Russian Academy of Sciences, \\ Makhachkala, Dagestan Republic, Russian Federation \\ y.djabrailov@yandex.ru
}

The article examines the hierarchy of social group identities types (all-Russian, regional, ethnic and religious) based on the results of monitoring the ethno-contact situation in the Republic of Dagestan, in the southernmost region of the Russian Federation. It explains the inconsistency of the sociological study results of on the prevalence of all-Russian identity in the collective consciousness of Dagestanis and at the same time their sense of social affinity with ethnic and religious groups. The author draws attention to the inadmissibility of contrasting ethnic and religious identities with national (civilian) identities and considers the thesis about the direct relationship between the growth of ethno-confessional identity and a decrease in the level of national identification invalid. Since representatives of traditional faith in the region do not support the anti-state views of extremist religious movements. The author believes that if ethno-confessional identity prevails over national identity, it should rather be about omissions in the politics of identity. The study reveals the internal and external reasons for the high level of ethno-confessional identity of the population of the republic. In general, the article notes the tendency of cognitive prevalence of national (state) identity among Dagestanis and the dominance in their minds of a favorable attitude towards multiple identification

Key words: national identity, ethnic identity, religious identity, culture, Republic of Dagestan.

\section{[Ю.Д. Джабраилов Этноконфессиональная и национально-государственная идентичность даге- станцев: современное состояние]}

На основе результатов мониторинга этноконтактной ситуации в Республике Дагестан, в самом южном регионе Российской Федерации, рассматривается иерархия типов социально-групповых идентичностей (общероссийской, региональной, этнической и религиозной). Разъясняется противоречивость результатов социологического исследования о превалировании общероссийской идентичности в массовом сознании дагестанцев и в тоже время их ощущение социальной близости с этническими и религиозными группами. Автор обращает внимание на недопустимость противопоставления этнической и религиозной идентичности национальной (гражданской) идентичности и считает несостоятельным тезис о прямой взаимосвязи роста этноконфессиональной идентичности с понижением уровня национальной идентификации. Поскольку представители традиционного вероисповедания в регионе не поддерживают антигосударственные воззрения экстремистских религиозных течений. Считаем, что в случае превалирования этноконфессиональной идентичности над национальной идентичностью, речь скорее должна идти об упущениях в политике идентичности. В исследовании раскрываются внутренние и внешние причины высокого уровня этноконфессиональной идентичности населения республики. В целом в статье отмечается тенденция когнитивного превалирования национальной (государственной) идентичности у дагестанцев и доминирование в их сознании благоприятного отношения к множественной идентификации.

Ключевые слова: национальная идентичность, этническая идентичность, религиозная идентичность, культура, Республика Дагестан.

Yusup Dz. Dzhabrailov - Ph.D. in Politics, Senior Research Fellow, Regional Centre of Ethnopolitical Researches, Daghestan Scientific Centre of Russian Academy of Sciences, Makhachkala, Republic of Dagestan, Russian Federation.

Джабраилов Юсуп Джабраилович - кандидат политических наук, старший научный сотрудник, Региональный чентр этнополитических исследований Дагестанского федерального исследовательского центра Российской академии наук, г. Махачкала, Республика Дагестан, Российская Федерация. 
For modern states civic identity is especially significant and valuable among types of social identities. It provides a consolidation of the society based on the priority of law, rights, historical and cultural community, through the formation of a sense of belonging to the state and civic nation. Does this mean that the process of formation of regional, ethnic, religious affiliation (i.e. other macroidentities) should be perceived as a threat to state integrity?

Unfortunately, at times, examples of oppositions of ethnic, religious and civic identity can be seen not only in the network. In fairly authoritative sociological studies on the questions "Who do you feel is primarily a citizen of a country or a representative of a particular religion or ethnic group". Strengthening the religious direction of socialization (religious identity) is considered in direct correlation with a decrease in state-national identity [2, p. 10]. Thus, the dominance of religious and ethnic identity is seen as an obstacle to building personal involvement in civil society and the Russian nation.

An analysis of the structure of the identification space of North Caucasian ethnic groups allows us to disagree with statements emphasizing the competing nature of ethnic and national identities, or the opposition of local characteristics of an all-Russian identity [3; 5].

The disunity of almost all the traditional faiths of the world into different directions and trends, sometimes adhering to directly opposite views on many issues, including the issue of the right to reside in a secular state and its attitude to it, also does not give grounds for unambiguous conclusions. A simple equal sign between religious identity and a particular model of the relationship of an individual with surrounding people, societies and a civil nation would be too much simplification. Accordingly, it is not entirely correct to consider religious identity in contrast with national-political self-identification. Perhaps, it makes sense to emphasize the understanding of religion on the part of individual radical movements, but not as an embodiment of the religious positions themselves.

As a rule, representatives of radical religious sects and movements are usually engaged in manipulating the consciousness of youth. They use plurality in the self-identification of Dagestanis to undermine the socio-political situation in the republic [10].

The Republic of Dagestan is the largest Muslim region in the Russian Federation. Ethnic Muslims make up 94\% of its population [6].

Due to ethno-cultural diversity, low indicators of socio-economic security and the specifics of political life, Dagestan is a special region of the Russian Federation. The aggravation of social problems here is a fertile ground for the manipulation of public consciousness and the opposition of certain types of identity.

The main part of the traditional Muslim clergy sees its mission in religious enlightenment, strengthening unity and brotherhood on the basis of common values, and a call for intercultural tolerance. In contrast, representatives of radical movements believe that the construction of a "state of justice" is possible only through forceful methods, through terror and violence. As a rule, Muslim leaders who do not support their methods and ideology take the first wave of violence. Building political goals, justified by religious texts taken out of context, the radicals themselves became tools in the hands of global political actors. Thus, radical movements have split among not only Muslims, but also imposed Islamophobia on society, which is one of the most acute problems in a multiconfessional and multinational country.

The main part of the traditional Muslim clergy sees its mission in religious enlightenment, strengthening unity and brotherhood on the basis of common values, and a call for intercultural tolerance. In contrast, representatives of radical movements believe that the construction of a "state of justice" is possible only through forceful methods, through terror and violence. As a rule, Muslim leaders who do not support their methods and ideology become the first victims. Building political goals, justified by religious texts taken out of context, the radicals themselves became tools in the hands of global political actors. Thus, radical movements have split among not only Muslims, but also imposed Islamophobia on society, which is one of the most acute problems in a multiconfessional and multinational country. 
In our opinion, the statement made at the meeting of the Council under Russia's President on Interethnic Relations that the problems of a low level of perception of civic identity is connected with the poorly developed model of multilevel identity in the country, according to which each type of social identity (family, religious, ethnic, civil, etc.) act as integral and harmoniously complementing the components in the formation of a full-fledged personality of a citizen of Russia. In fact, they do not contradict each other and do not replace others, but are designed to satisfy the needs of understanding oneself and the world around us, family ties, ethnic culture, ties with a small homeland and spiritual moral standards, their civil rights and the possibility of self-realization.

Therefore, it is important to convey to young people that not a single kind of identity from the whole set of their multi-level identity is superfluous or main or replacing another. They are all parallel on the level of social relations, not contradicting each other, but rather reinforcing the personality [4].

The annual monitoring carried out by the Regional Center for Ethnopolitical Studies (the survey is conducted in at least twenty city and district municipalities), the ethno-contact situation in the municipalities of the Republic of Dagestan shows some inconsistency in the hierarchy of types of social group identities in the mass consciousness of Dagestanis.

So, according to the survey which provided a question: "Whom can you say about: "We are ..." (several answers could be chosen), the concept of "Russian identity" unconditionally leads the public mind of Dagestanis (69.3\% of the total number of respondents ) The second place among respondents is their association with "people of the same faith" (23.3\%), then with "fellow countrymen" (20.2\%). Ethnicity as a collective self-identification was noted by only $9 \%$ of respondents, next only (in addition to the three leading aspects of identity) to such communities as: "people of the same outlook on life" (17.5\%), "residents of my city, village" (15.8\%); "people strictly observing the laws" (15\%) [1, p. 61].

At the same time, the distribution of answers to the question: "How close do you feel with Dagestanis, with representatives of your people, with Russians, with people of your faith?" (several answers could be chosen) shows that the item "social proximity with Russians" is in a closed position. Together, "very close" and "close" with Dagestanis are gaining a total of $59.4 \%$ (42.3\% and $17.1 \%$ respectively), with people of my faith $-44.2 \%$ (29.9\% and $14.3 \%)$, with representatives of their people - $41 \%$ (29.8 \% and $11.2 \%)$ and with Russians $33.6 \%(18.6 \%$ and $15 \%)$.

Thus, in the hierarchy of types of social identity in the mass consciousness of Dagestanis, on the one hand, the all-Russian identity clearly prevails, and on the other hand, the identification of a sense of community with social groups indicates the dominance of regional and religious identity.

It must be clarified that citizenship as a status is a dual phenomenon. On the one hand, an individual is a citizen to the extent that he obtains rights and responsibilities in the state, on the other hand, a citizen to the extent that he identifies with the community of individuals as a whole. Moreover, here there may be an interesting situation. Civil status in the state and in the membership of a community of individuals can carry a different semantic load [7, $p$. 46].

So, the study of the attitude of respondents to a particular group reveals that the majority of respondents prefers to perceive themselves, first of all, as Russian citizens, but the results of measuring social proximity with a particular social group show that state-civic identity is far from the first place. In this regard, Dagestanis feel, first of all, a close connection with social groups according to ethno-confessional parameters. The results of the study about "some degree" of respondents' perception of themselves as part of modern Russian society speak, rather, of the result of their disappointment in certain aspects of identity politics. 
Therefore, there is a problem of manifestation of state-civil identification and patriotic feelings only in a declarative and protective manner, and not at the level of deep involvement and responsibility for the development of Russian society and the country as a whole.

Thus, in order to strengthen civic identity, it is necessary to concentrate attention not only on the development of common values, but also on ensuring in real life equal opportunities for an individual regardless of his ethnocultural characteristics. However, unfortunately, in the mass consciousness of people the constitutional provision on the equal rights of all Russian peoples is not perceived as a norm. According to the results of a sociological study conducted by the Institute of Sociology of the Russian Academy of Sciences, no more than half of the population shares the opinion that in the state people of all nationalities should have equal rights, and in the national republics, it is shared by 80 to $90 \%$ of the population, including Russians. This imbalance presents an obvious risk that the state and society have to overcome [8, p. 20].

Thus, the problems of strengthening civic identity are mostly associated, as a rule, with the quality of ensuring social justice and stability in the country, the dominance in the practice of social communication of the cult of law, the rights, honor and dignity of people regardless of nationality and religion.

The compatibility of civic self-identification with ethno-confessional self-consciousness is widely represented and manifests itself in multiple identities. So, to the question: "What do you feel like more: more likely a person of your nationality or more likely a Russian?" $49.8 \%$ of respondents answered: "equally to both." To the question: "What do you feel like to a greater extent: more likely a Dagestan or more likely a person of your nationality?" $46.7 \%$ of respondents answered "equally to both." Moreover, choosing between the Russian (civil) and Dagestan (regional) identities, $43 \%$ of respondents answered "to both, equally"; $39.8 \%$ are more likely a Dagestan and $17.1 \%$ are more likely a Russian.

In this regard, the conclusion that increased religious and ethnic self-consciousness impedes individuals in participating in civil society is not entirely logical. On the contrary, the fragmentation of Russian society at the level of social interaction in terms of socio-status, territorial and ethnocultural parameters contributes to an ever-greater identification of the individual with those social groups with which he feels the community of his roots.

Consequently, if indicators of civic identity do not dominate the mass consciousness of the country's population, it should rather be about omissions in national (state) policy. The effectiveness of the nation-building process largely depends on whether they will be perceived in Russian society as their (close) elements of ethno-confessional cultures of the peoples of Russia, as full-fledged components of the all-Russian cultural code.

The high level of ethno-confessional consciousness of the Dagestanis is explained, in our opinion, by internal and external causes. If we talk about internal, then ethnic values and norms are historically sustained methods of social integration. As for religion, for many centuries it has been an important part of the ethnic culture and psychology of Dagestanis, and its significance is caused by the need to communicate with God as a condition for the existence and socialization of believers.

The external reasons for the increase in religiosity in the region are, in our opinion, related to new trends coming from the West, according to which a new social reality is being created. They clearly show a tendency to reformat the understanding of the institution of the family, the issue of social solidarity and moral principles that has developed throughout the history of the formation of human civilization.

Muslim communities are more sensitive to these modern trends of social transformations and attempts to impose on society as a whole the low-level values of "mass culture". Under these conditions, religious self-awareness as the most conservative form of identification becomes dominant among other social identities. 
Thus, the high level of religious self-identification is partly explained by the desire to get out of the state of social helplessness, through the awareness of one's belonging to a particular religion. Religious values, norms and rules of behavior for many centuries have proved their effectiveness in ensuring stability and value orientation in a dynamic world. The pattern of development of any culture is the continuity in the transfer and preservation of its values, since humanity needs to reproduce itself and self-regulate [9, pp. 195-198].

In addition, the post-Soviet transformation of the socio-political system radically changed the legal basis of state-confessional relations, updated the appeal and study of the rich religious heritage in the region. That is a question the opposition of some types of identity is the cause of a large number of conflicts in Russian society. Maintaining equal rights for all forms of identities is an important condition for achieving the integrity of the entire system of ethno-national and civil relations in a single country. A state where many faiths and ethnic groups coexist should be a regulator of the process of taking their interests into account without any distortions. The unity of the Russian nation is achieved not by imposing the priority of some social identities over others, but by implementing the legislative rights of citizens to multiple identification. A model of multilevel identity, where family, ethnic, religious, civil and other types of identities are integral and harmoniously complementing the formation of a fullfledged personality of a citizen of Russia.

In general, the results of a study of the hierarchy of types of social identity among residents of the republic show a variety of combinations of civil, ethnic, regional (Dagestan), religious self-awareness with cognitive prevalence of state-civic identity and high emotional significance for the Dagestanis of their communal, regional, ethnic and religious identity .

Currently, the consistent strengthening of Russian national self-consciousness is hindered by the lack of a state policy for the transition from ethnic particularism to national-civic universalism.

\section{Лumepamypa}

1. Абакаров Р.И. Мониторинг межэтнических отношений в Республике Дагестан. Социально-политические науки Том IX. № 6. 2019. С. 61

2. Абдулагатов 3.М. Религия в системе идентичностей молодежи Республики Дагестан. Исламоведение. 2012. № 4. С. 10

3. Авксентьев В.А., Аксюмов Б.В. Портфель идентичностей молодежи юга России в условиях цивилизационного выбора // Социс. 2010. № 12. С. 18-27.

4. Владимир Путин на заседании Совета по межнациональным отношениям [Электронный ресурс] https:// www.youtube. com/watch? v=pZYyM_ozF7g (дата обращения - 23.01.2020)

5. Вшивцева Л.Н. Культурно-цивилизационная самоидентификация народов Северного Кавказа в контексте модернизации // Стратегическое планирование в полиэтничном макрорегионе в условиях неравномерного развития и роста напряженности: материалы Всероссийской научной конференции. Ростов-наДону, 3-4 октября 2013 г. / отв. ред. акад. Г.Г. Матишов. Ростов н/Д: ЮНЦ РАН, 2013. С. $170-174$.

6. Двадцатка самых исламизированных регионов России [Электронный ресурс] https://islamtoday.ru/islam_v_rossii/dvadczatka_samyx_islamizirovannyx_regionov_ro ssii/ (дата обращения - 11.03. 2020)

7. Джабраилов Ю.Д. К вопросу о политике идентичности в Российской Федерации. Гуманитарные и социальные науки. №5 2019. С. 46

8. Дробижева Л.М. Динамика гражданской идентичности и ее ресурс в позитивных интеграционных процессах российского общества // Мониторинг общественного мнения: Экономические и социальные перемены. 2017. №4. 
9. Ляушева C.A., Нагой А.А. Религиозная идентичность в современной культуре // Вестник адыгейского государственного университета. Серия 1: регионоведение: философия, история, социология, юриспруденция, политология, культурология. 2009. №1. С. 195-198.

10. Ниналалов С. Камиль Ланда: «По постам и лайкам можно собрать портрет». [Электронный https://dag.aif.ru/society/kamil_landa_po_postam_i_laykam_molodogo_cheloveka_mo zhno_sobrat_portret (дата обращения: 21.02.2020)

\section{References}

1. Abakarov R.I. Monitoring mezhetnicheskikh otnosheniy v Respublike Dagestan. Sotsialno-politicheskiye nauki. [Monitoring interethnic relations in the Republic of Dagestan. Socio-political sciences]. Volume IX. No. 6. 2019. 61 p. (In Russian).

2. Abdulagatov Z.M. Religiya v sisteme identichnostey molodezhi Respubliki Dagestan. Islamovedeniye. [Religion in the youth identity system of the Republic of Dagestan. Islamic studies]. 2012. No. 4. 10 p. (In Russian).

3. Avksentiev V.A., Aksyumov B.V. Portfel identichnostey molodezhi yuga Rossii v usloviyakh tsivilizatsionnogo vybora. [The identity portfolio of youth of the south of Russia in the context of civilizational choice]. Socis. 2010. No. 12. pp. 18-27 (In Russian).

4. Vladimir Putin na zasedanii Soveta po mezhnatsionalnym otnosheniyam. [Vladimir Putin at a meeting of the Council on Interethnic Relations]. Available at: https:// www.youtube. com/watch? v=pZYyM_ozF7g. (In Russian).

5. Vshivtseva L.N. Kulturno-tsivilizatsionnaya samoidentifikatsiya narodov Severnogo Kavkaza v kontekste modernizatsii. Strategicheskoye planirovaniye $v$ polietnichnom makroregione $v$ usloviyakh neravnomernogo razvitiya i rosta napryazhennosti: materialy Vserossiyskoy nauchnoy konferentsii. Rostov-na-Donu, 3-4 oktyabrya 2013 g. [Cultural and civilizational self-identification of the peoples of the North Caucasus in the context of modernization. Strategic planning in a multi-ethnic macro-region under conditions of uneven development and growing tension: materials of the All-Russian Scientific Conference (Rostov-on-Don, October 3-4, 2013)]. Rostov-on-Don. 2013. pp. 170-174. (In Russian).

6. Dvadtsatka samykh islamizirovannykh regionov Rossii. [The twenty most Islamized regions of Russia.] Available at: https://islamtoday.ru/islam_v_rossii (In Russian).

7. Dzhabrailov Y.D. K voprosu o politike identichnosti v Rossiyskoy Federatsii. Gumanitarnyye i sotsial'nyye nauki. [On the issue of identity policy in the Russian Federation. Humanities and social sciences]. No. 5. 2019. 46 p. (In Russian).

8. Drobizheva L.M. Dinamika grazhdanskoy identichnosti i yeye resurs $v$ pozitivnykh integratsionnykh protsessakh rossiyskogo obshchestva. Monitoring obshchestvennogo mneniya: Ekonomicheskiye i sotsial'nyye peremeny. [The dynamics of civic identity and its resource in the positive integration processes of Russian society. Public Opinion Monitoring: Economic and Social Change]. 2017. No. 4. (In Russian).

9. Lyausheva S.A., Nagoy A.A. Religioznaya identichnost v sovremennoy kulture. Vestnik adygeyskogo gosudarstvennogo universiteta. Seriya 1: regionovedeniye: filosofiya, 
istoriya, sotsiologiya, yurisprudentsiya, politologiya, kulturologiya. [Religious identity in modern culture. Bulletin of the Adyghe State University. Series 1: regional studies: philosophy, history, sociology, jurisprudence, political science, cultural science]. 2009. No. 1. pp. 195-198 (In Russian).

10. Ninalalov S. Kamil Landa: «Po postam i laykam mozhno sobrat portret». [Camille Landa: "You can put together a portrait by posts and likes."]. Available at: https://dag.aif.ru/society/kamil_landa_po_postam_i_laykam_molodogo_cheloveka_mo zhno_sobrat_portret. (In Russian). 